\title{
OBITUARIES
}

\section{Dr. Bashir Ahmad}

Dr. Bashir Ahmad, who died suddenly in the home of his friend and colleague, Colonel M. K. Afridi, at the University of Peshawar on March 14, was an unassuming man who had won the position he held in the scientific life of Pakistan by his ability in many fields. A devout Moslem, he received his early scientific training at the non-denominational Forman Christian College in Lahore, afterwards gravitating towards biochemistry and nutrition, and working for three years from 1928 with Prof. J. C. Drummond at University College, London.

This was an experience he never forgot, and which not only shaped his future career in chemistry but also gave him a sympathy for and understanding of Britain which was never shaken. On returning to India he became a lecturer in chemistry, and eventually professor of organic chemistry in the University of the Punjab. There he continued his work on carotenoids. Later he joined Sir Shanti Bhatnagar in the Indian Department of Scientific and Industrial Research, and transferred to Calcutta, where he became interested in the B group of vitamins.

On partition of India, he opted for Pakistan and returned to Lahore as head of the Institute of Chemistry, and became eventually vice-chancellor of the University of the Punjab. It was during his tenure of this office that he came to Cambridge for the Congress of the Commonwealth Vice-Chancellors, and received the honorary degree of LL.D., a tribute of which he was very proud, as he was of his more recent election as a Fellow of University College, London. In 1953 he was asked by the Pakistan Council for Scientific and Industrial Research to be director of the West Regional Laboratory at Lahore, one of the three regional laboratories established by the Council.

The progress of this Laboratory is characteristic of his skill and energy as an organizer. The preliminary plan of work, and the outlines of the main divisions, came from the committee of which he was chairman in that same year. Work began in a limited way in the Institute of Chemistry, and in $1955 \mathrm{a}$ magnificent site on the Ferozepur Road, adjoining the new buildings of his old College, the Forman Christian College, had been acquired. 1956 saw the completion of one building, and this summer will see two more splendid new institutes finished, with spacious workshops, and houses for the staff.

In a country which is short of well-trained men, more and more burdens are placed on the shoulders of those willing to accept them. Dr. Bashir Ahmad organized and ran the Pakistan Association for the Advancement of Science, edited its publications, examined at the Universities of Dacca and Karachi, organized local meetings of World Brotherhood, was in process of organizing an Urdu Academy, led scientific missions to China, and ultimately had so little leisure that he could not take the rest which his medical adviser ordered.

Dr. Ahmad's scientific researches are known to workers in nutrition, and will not be forgotten, but it is not for this that he will mainly be missed. He will be missed by his country as a scientist (and above all because he was the only well-trained nutrition worker in Pakistan), by those who knew him and had had the rare privilege of working with him in building up his new organization and visiting his home and family, and most of all by the young graduates who, feeling rather lost in the underdeveloped country into which graduation thrust them, found in him a man who never failed them with sympathy, help and advice. To half Lahore and countless students in both West and East Pakistan he was 'Doctor Bashir' or 'Doctor Sahib'. Men were willing, once they knew him, to work at Lahore for less than they could get in industry. "No man is an island" is a truth which Pakistan will come more and more to realize in years to $\operatorname{com} \theta$, and one who knew his plans for Lahore and what they meant to him and would have meant to Pakistan can only hope that his labours will not have been in vain.

$$
\text { J. C. FIDLER }
$$

\section{Mr. K. W. Tremellen}

Kenneth William Tremeluen, who died on April 3, was one of the pioneers in radio research. He gained his experience in handling radio receivers when he was an assistant to Captain H. J. Round in the Marconi Company in the years before the First World War, and he did outstanding work in Flanders, using some of the early valve sets in the interception of radio signals and in locating enemy transmitters by a network of direction-finding stations. In particular, he plotted the Zeppelin raids and the movements of the German Fleet.

It was natural that he should be chosen later by the Marconi Company to undertake a journey around the world making field-strength and direction-finding measurements of the long-wave stations and of atmospherics. The mass of information thus obtained. formed the material for a classical paper jointly with Eckersley, Round and Lunnon. With the advent of short-wave communications he began a long series of observations which supplied most of the data around which T. L. Eckersley wrote his remarkable papers published by the Institution of Electrical Engineers. This work included some of the earliest records of scattered signals and around-the-world echoes.

The present system of charts of world-wide ionospheric conditions published each month by various organizations had their origin in the 'shadow charts' which he devised thirty years ago. At the beginning of the Second World War he was already constructing quite detailed charts based largely on his personal knowledge of high-frequency propagation conditions, and he played a leading part as the scientific officerin-charge of the Inter-Services Ionosphere Bureau established at Great Baddow, for which he was awarded the American Medal of Freedom.

'Trem', as he was affectionately known to all his friends, was an experimenter with a genius for careful and patient observation and for distinguishing between reliable and spurious results. He made no claim to be an expert in mathematics or physics, but he had a healthy scepticism towards erudite theoretical papers reared on highly conjectural hypotheses or doubtful experiments. It was not unusual when reading a journal that had already passed through his hands to come across such marginal comments as "so what ?" or "very fluffy". 
He was a modest man of great courtesy and as a bachelor he led a quiet and simple life. On his retirement in 1952 , he went to live with friends in south-east London, where he found great pleasure in gardening and some of the domestic arts. He retained one link with radio, for he continued to serve in a personal capacity on the Ionospheric Communications Committee of the Department of Scientific and Industrial Research, where his knowledge of shortwave circuits was invaluable. When he attended the meeting on March 29 he was obviously failing in health, but it came as a shock to hear a week later that he had died within a few hours of being taken suddenly ill.

His unique knowledge of propagation conditions was of a kind that was difficult to commit to paper. $\mathrm{He}$ wrote comparatively little, and with his passing the world of radio has suffered a great loss.

G. Millington

\section{Dr. G. E. Foxwell, C.B.E.}

Geoffrey Edwin Foxwell, who died on April 26 after a short illness, was born in 1892. He obtained his early education at the Hinckley Grammar School and at All Saints' School, Bloxam. His first appoint. ment in science and fuel technology was as a junior chemist with the Koppers Coke Oven and ByeProduct Co. of Sheffield, where he soon showed ability well above the average. In 1916, at the early age of twenty-four, he became coke oven manager to the Alloa Coal Co., but later returned to the Koppers Company as chief chemist. During this period his energy and drive were such that he took the B.Sc. degree of London and later gained the D.Sc. degree for outstanding work on the plastic state of coal.

In 1924 Foxwell was appointed senior research chemist to the Gas Light and Coke Company in London, but remained only a short time before again returning to the Koppers Company as chief technical officer. He finally left full-time service with that Company in 1932, though retained for a time as consultant, to move to London to take up various professional activities. These activities included a close association with Clayton, Son and Co., of Leeds, gas and constructional engineers, and considerable work in technical journalism. His articles were always clear, interesting and informative, and it was in this field that he excelled.

Foxwell's interests were by no means narrow. During the Second World War he was successively vice-chairman and chairman of the British Chemical Plant Manufacturers' Association, and a member of the Fuel Efficiency Committee of the Ministry of Fuel and Power. He was also editor, and author of several chapters, of the book, "The Efficient Use of Fuel", first published in 1944 by H.M. Stationery Office. A founder member of the Institute of Fuel, he served on the Council of the Institute continuously from 1942 and was president during 1951-53. He was a prominent member of the Committee on Air Pollution under the chairmanship of Sir Hugh Beaver. $\mathrm{He}$ was made C.B.E. in the Birthday Honours List of 1955. His outside interests included the chairmanship of the Epsom Sports Club and he was an active player of cricket to the end.

Foxwell never spared himself. He was thorough and painstaking in whatever task he undertook, and always friendly, helpful and considerate.

\section{A. PARKER}

\section{NEWS and VIEWS}

\section{Civil Aircraft Research and Development, Ministry of Supply: \\ Mr. J. M. Gray}

Mr. J. M. GRAY retired from the post of director of Civil Aircraft Research and Development with the Ministry of Supply in April 1957, after thirty-five vears in the Government Service. $\mathrm{H}_{e}$ was born in Lairg, Sutherland, in 1896, and after serving in the R.N.A.S. and R.A.F. for three and a half years in the First World War he entered the University of Glasgow, where he graduated in engineering, including aeronautics as a special subject. In $1923 \mathrm{he}$ joined the Airworthiness Department of the Royal Aircraft Establishment and was engaged in assessing the structural and aerodynamic qualities of aircraft designs, both military and civil. $\mathrm{He}$ assisted in preparing and compiling the first editions of the wellknown aircraft handbooks A.P.970 and A.P.1208. The latter was eventually absorbed in "British Civil Airworthiness Requirements", now issued by the Air Registration Board. Mr. Gray also assisted in instituting the Approved Firms Scheme in conjunction with the Resident Technical Officer Organization, which he supervised until 1931. During that period he produced a "Handbook of Aerodynamic Calculations" for the use of the Department and resident technical officers.

In 1931 he was transferred to the Air Ministry. During his first year there he initiated and developed new mothods for the more rapid checking of performance estimates for tender designs. These methods were afterwards published in the "Handbook of Aeronautics". After a further brief posting to the Royal Aircraft Establishment, Mr. Gray was recalled in 1937 to the Air Ministry to assist the newly appointed director of Civil Aircraft Research and Production. During the War he was, until 1944, concerned mainly with the development of equipment and installations for military aircraft and he headed a mission to the United States to investigate progress of these items in that country. In 1944 he headed a small section in the Ministry of Aircraft Production, set up to co-ordinate the development of post-war civil aircraft and associated equipment. During this period he acted as technical adviser to the Brabazon Committee. $\mathrm{He}$ accompanied Lord Winster's delegation in 1946 as technical adviser, to take part in the South Pacific Air Transport Council in New Zealand, which was in the process of setting up the British Commonwealth Pacific Airlines. During the latter part of his career he was closely associated with the development of civil transport aircraft for the Airline Corporations, such as Britannia, Comet and Viscount.

Mr. H. Templeton

Mr. H. Templeton has been appointed to succeed Mr. Gray. He was born in 1914. After taking a 